NBER WORKING PAPER SERIES

\title{
THE DRAW OF HOME: HOW TEACHERS' PREFERENCES FOR PROXIMITY DISADVANTAGE URBAN SCHOOLS
}

\author{
Donald Boyd \\ Hamilton Lankford \\ Susanna Loeb \\ James Wyckoff \\ Working Paper 9953 \\ http://www.nber.org/papers/w9953
NATIONAL BUREAU OF ECONOMIC RESEARCH
1050 Massachusetts Avenue
Cambridge, MA 02138
September 2003

We thank Istvan Vanyolos for research assistance. We are grateful to the Smith Richardson Foundation, the Office of Educational Research and Improvement, U.S. Department of Education, and the New York State Department of Education for financial support. They do not necessarily support the views expressed in this paper. Any errors are attributable to the authors. The views expressed herein are those of the authors and not necessarily those of the National Bureau of Economic Research.

C2003 by Donald Boyd, Hamilton Lankford, Susanna Loeb, and James Wyckoff. All rights reserved. Short sections of text, not to exceed two paragraphs, may be quoted without explicit permission provided that full credit, including $(\mathbb{C}$ notice, is given to the source. 
The Draw of Home: How Teachers' Preferences for Proximity Disadvantage Urban Schools Donald Boyd, Hamilton Lankford, Susanna Loeb, and James Wyckoff

NBER Working Paper No. 9952

September 2003

JEL No. I2, J2, J3, J4, J6

\section{ABSTRACT}

This paper explores a little understood aspect of labor markets, their spatial geography. Using data from New York State, we find teacher labor markets to be geographically very small. Teachers express preferences to teach close to where they grew up and, controlling for proximity, they prefer areas with characteristics similar to their hometown. We discuss implications of these preferences for the successful recruitment of teachers, including the potential benefits of local recruiting and training. We also discuss implications for the modeling of teacher labor markets, including the possible biases that arise in estimates of compensating differentials when distance is omitted from the analyses. This study contributes to the literature on the geography of labor markets more generally by employing data on residential location during childhood instead of current residence, which may be endogenous to job choice.

\author{
Donald Boyd \\ University at Albany \\ SUNY \\ 1400 Washington Avenue \\ Albany, NY 12222 \\ boydd@rockinst.org \\ Hamilton Lankford \\ University at Albany \\ SUNY \\ 1400 Washington Avenue \\ Albany, NY 12222 \\ hamp@albany.edu
}

\author{
Susanna Loeb \\ Stanford University \\ 224 CERAS, 520 Galvez Mall \\ Stanford University \\ Stanford, CA 94305 \\ sloeb@stanford.edu \\ James Wyckoff \\ University at Albany \\ SUNY \\ 1400 Washington Avenue \\ Albany, NY 12222 \\ wyckoff@albany.edu
}




\section{Introduction}

School districts across the country are finding it increasingly difficult to recruit new, well-qualified teachers. This is especially true for urban schools with high concentrations of poor, non-white, and low-performing students. States and school districts have responded with a variety of policies to attract and retain more qualified teachers in these difficult-to-staff schools. Some states and districts employ signing bonuses; others have mounted aggressive, often farreaching, recruitment campaigns to attract prospective teachers. Still other efforts focus on broadening entry to the profession through alternative certification programs.

Policies to attract and retain teachers develop with little guidance from research. The nature of the labor market for teachers is complex, involving the interaction of a wide variety of institutions, policies, and practices, the result of which affects both the supply and demand for teachers. In this paper, we explore a little understood but potentially important feature relating to the recruitment of more qualified teachers to schools: the geographic scope of teacher labor markets. We are particularly interested in how prospective teachers delineate the geography of their job search. How broadly are teachers dispersed from prior places of residence and what attributes of teachers affect this geographic span? We find that teachers delineate their job searches to relatively small geographic areas, very close to where they grew up. While preferences vary somewhat by the characteristics of the individual teachers, distance appears important for all groups of teachers that we analyze.

The preference for geographic proximity has implications for policies regarding the training and recruitment of teachers, suggesting potential benefits of local recruitment and training. It also has implications for how models of teacher labor markets are conceptualized, given that the omission of distance as a factor in teachers' choices may bias estimates of compensating differentials, and, more generally, of teachers preferences for various job characteristics.

The next section of the paper motivates our interest in examining the geography of teacher labor markets and reviews research pertaining to the geography of labor markets. Section three describes the data. The fourth section examines the geographic scope of teacher labor markets both descriptively and through a behavioral model. The final section summarizes these findings and examines their application to policy issues in the recruitment of teachers. 


\section{Background}

Lankford, Loeb and Wyckoff (2002), using several measures of teacher characteristics, find that there is wide variation in the qualifications of teachers across schools. Urban schools and those with lower-performing students are much less likely to employ highly qualified teachers. ${ }^{1}$ Table 1 shows that in schools where more than 20 percent of the students performed at the lowest level on the $4^{\text {th }}$ grade English Language Arts (ELA) exam, 35 percent of the teachers had failed the general knowledge portion of the certification exam at least once compared to 9 percent among teachers in schools in which none of the students had scored at the lowest level on the $4^{\text {th }}$ grade ELA exam. Correlations between school achievement and teacher characteristics tell a similar story; the proportion of a school's students who achieved at Level 1 has a 0.63 correlation with the proportion of that school's teachers who are not certified to teach any of their current courses. The correlations for the proportion failing either the National Teacher General Knowledge Exam or the New York State Teacher Certification Liberal Arts and Science exam are both 0.50 , and the correlation of student achievement with teacher graduation from a less competitive college is 0.41 . The results are similar if we use the $4^{\text {th }}$ grade mathematics exam or the $8^{\text {th }}$ grade ELA and math exams. Similar results also hold if students are partitioned by race or poverty status. The results of these analyses are clear. There is strong evidence that students in difficult-to-staff schools are taught by the least qualified teachers.

What accounts for this extraordinary sorting of teachers? It could result from either sorting of teachers in their first job placements or from differential exits and transfers that cause more qualified teachers to leave low-performing schools and transfer to higher performing schools. Boyd, Lankford, Loeb and Wyckoff (2002) find that although both explanations

\footnotetext{
${ }^{1}$ Measures of teacher qualifications include: the percent of teachers not certified in any current teaching assignment, the percent of exam takers who failed the National Teacher General Knowledge Exam or the New York State Teacher Certification Liberal Arts and Science exam on their first attempt, the percent who attended colleges Barron's College Guide rated most competitive and highly competitive schools, the percent who attended competitive, less competitive, or least-competitive colleges.

New York's student achievement data for $4^{\text {th }}$ and $8^{\text {th }}$ grade English Language Arts (ELA) and Math place each student's test results in one of four performance levels. The school data indicate the number of students in each level. To examine low-performing students we employed the portion of the students tested whose results place them in the lowest performance group, Level 1. Level 1 for $4^{\text {th }}$ grade ELA is described by the New York State Education Department as, "These students have serious academic deficiencies. They show no evidence of any proficiency in one or more of the elementary standards and incomplete proficiency in all three standards."
} 
account for some of the sorting of teachers, first job placements that match less-qualified teachers with lower performing schools are generally most important. Because of this, we focus our analysis on the location of job search behavior of entering teachers.

There is a large and rapidly growing literature on job search and labor market segmentation (see Martin (2000) for a review). Much of the recent research has concentrated on issues of market segmentation and spatial mismatch. That work focuses on the extent to which differential access to employment is related to residential segregation (spatial mismatch) and social networks (market segmentation). Although distance can be an important component to hypotheses concerning spatial mismatch and market segmentation, much of this research embeds distance in a discussion of interpersonal relationships and institutional access. This research frequently employs two alternative approaches - analyses of distance from home to work and surveys of employees and/or residents concerning their job search activities.

Researchers examining the spatial mismatch hypothesis often use Census data to examine the attributes of individuals, residential neighborhoods, commuting patterns and occupation within a particular metropolitan area (Scott, 1992). This research frequently finds support for the spatial mismatch hypothesis that racial and ethnic minorities live in neighborhoods further from more attractive employment opportunities, reducing their likelihood of being hired.

Market segmentation research relies on relatively small-scale surveys to better understand how personal and social networks affect employment outcomes (Hanson and Pratt, 1992). This research documents the importance of social networks in connecting individuals to employment opportunities. Labor markets are found to be 'local', although local is more complex than distance. Nonetheless, this research also finds that labor markets are often geographically small, either because distance is an important component of the theory (spatial mismatch) or because distance is negatively correlated with development of networks that underlie market segmentation.

As Martin (2000) observes, workers frequently exhibit a strong attachment to place which results in the 'spatial fixity' of local labor and the accompanying potential for differences in wages and other attributes across local labor markets. Additionally, residential immobility and sorting create segmented labor markets even within what would be considered typical travel to work areas. Thus, the emerging literature on local labor markets suggests that labor market 
segmentation creates the potential for markets within markets where differences in wages, working conditions and worker qualifications can be maintained over extended periods of time.

Gregory and Borland (1999) review the literature on public sector labor markets and suggest that markets for teachers may reflect restricted geographic scope and exhibit little interdependency with private-sector labor markets, which could lead to differences in the qualifications and terms of employment for teachers within relatively small geographic areas. Notably, however, Gregory and Borland, however, do not identify any studies that examine the geographic scope of labor markets.

The empirical literature examining the geography of labor markets provides evidence on the importance of the spatial and social interactions of employers and employees within relatively small geographic areas. The underlying assumption of most of this work is that individuals have chosen to live in particular locations and explore their employment opportunities conditional on that residential location. One potential problem with this approach is the endogeneity of residential location. Workers may choose their residence with a view towards employment prospects. In this paper we are able to avoid this problem by using data on residential location during high school. A second potential problem with assessing preferences for geographic proximity to home is separating employers' preferences from employee's preferences. In this paper, we reduce this difficulty by assessing the choice of region of work, instead of the choice of specific jobs. We, thus, do not assume that employees have choice over all jobs, but use a much weaker restriction that employees have choice over region of work. As reported below, we find substantial evidence that distance plays an important role in job choice. These preferences can explain some of the relative disparities in employee qualifications across schools and the relative difficulty of urban schools in attracting teachers.

\section{Data}

We examine the geography of teacher labor markets by linking the locations of New York teachers at several points during their lives. We observe where individuals take their first public school teaching position. For a majority of these teachers we know their residential location during high school (hometown) and for most of them we know where they attended college before taking their first job. Based on this information, we examine the relationship between the region of a teacher's first teaching job and the locations of his/her hometown and 
college. We also explore how other attributes of teachers (e.g., gender or the qualifications of teachers) and of place (e.g. urbanicity) affect the geographic scope of teacher labor markets.

Our database links six administrative datasets and various other information characterizing districts, communities, and local labor markets. It includes information for every teacher and administrator employed in a New York public school at any time from 1984-85 through 2001-2002. The core data comes from the Personnel Master File (PMF), part of the Basic Education Data System of the New York State Education Department. In a typical year there are approximately 200,000 teachers identified in the PMF. Several other databases that contain a range of information about the qualifications of prospective and actual teachers, as well as the environments in which these individuals make career decisions, substantially enrich this core data. Based on records from the College Board, the State University of New York, applications for teacher certification, and current employment information, we know the locations of teachers at various points during their lives. We also know the attributes of students, schools, and as described above, the qualifications of teachers. See Appendix A for a description of the administrative datasets that we have linked together for this analysis. In our analysis, teachers choose the location of their first job from one of 17 different regions - the urban or suburban regions of seven different Metropolitan Statistical Areas (MSAs), and three rural regions of New York State. These areas exhaust the geography of New York State.

We identified the hometown from the location of the high school they attended when they took the SAT exam or the address they used when they applied to college. ${ }^{2}$ This information is known for individuals who took the SAT in a New York secondary school since 1980 or anyone who applied to any of the 64 State University of New York colleges or universities since 1990. These data sources provide a hometown for 59 percent of the first-year teachers hired from 199899 through 2001-02 (1999-2002). Hometown data is available for 49 percent of the teachers whose first job is in a New York City public school. It is possible that there is a selection bias associated with the hometown variable — individuals who did not take the SAT in New York or did not apply to a SUNY college may be more likely to have hometowns further from their first job than those for whom we observe hometown. We do observe the location of the college teachers attended for over 86 percent of all first-year teachers and 73 percent of the first-year teachers for whom we do not observe hometown. We have duplicated all of the analyses

\footnotetext{
${ }^{2}$ When both data elements are present and conflict, we employ place of residence.
} 
presented in this paper using the expanded sample substituting college location and distance from college to first job for information based on hometown. Doing so does not change any of the substantive conclusions presented.

Our approach to understanding teacher labor market geography is to examine descriptive relationships, and then develop a behavioral model of first-job location for newly hired teachers.

\section{Labor Market Geography}

Descriptive analysis. Most public school teachers take their first public school teaching job very close to their hometowns or where they attended college. Sixty-one percent of teachers entering public school teaching in New York from 1999 to 2002 started teaching in regions located within 15 miles of their hometown (Table 2). Eighty-five percent entered teaching within 40 miles of their hometowns. Table 2 presents results separately by metropolitan area. In each of the regions teachers take first jobs very close to home, however, there are differences. For example, in New York City, 90 percent of all teachers take a first job within 40 miles of their hometowns while in the City of Rochester, only 65 percent of novice teachers took jobs within 40 miles of home.

Although 41 percent of first-year teachers are missing a hometown variable, this does not appear to bias these findings. Those observations with hometown missing but for whom college location is known are just as likely to take a job within 15 miles of the college from which they received their most recent degree (37 percent) as observations for which hometown is available (37 percent) (Appendix Table B-1).

Table 3 shows that hometowns have a somewhat greater pull than place of college. Of those who received their most recent degree at least 100 miles from home (24 percent of all observations), 48 percent took jobs within 15 miles of their homes and 72 percent within 40 miles of home. These teachers went 'away' to college but returned home to work. In contrast, of those teachers who took jobs at least 100 miles from home (7 percent of all observations), only 17 percent were within 40 miles of the institution at which they had received their most recent degree.

These patterns may reflect more than just preference for proximity. For example, individuals may search for employment in regions with which they are familiar, independent of the distance from their hometown. These similarities may be specific to their hometown region, 
e.g., familiarity with a specific school system, or more generically to a type of situation, e.g., familiarity with urban school environments. Over 90 percent of the individuals whose hometown is New York City and who entered public school teaching from 1999 to 2002 first taught in New York City (Table 4, row percentage). About 60 percent of those having hometowns in the New York City suburbs first taught in those suburbs. Other major urban areas follow a similar pattern. Teachers with hometowns in urban locations are more likely to take a first job in that urban district relative to its suburbs, and those whose hometown is in the suburbs are much more likely to initially teach in those suburbs, rather than the nearby urban district (Table 5). Eighty-eight percent of teachers whose hometown is in an urban district first teach in an urban district, although only 60 percent of urban teachers come from urban hometowns. Fully 36 percent of urban teachers originate in the suburbs, while only 6 percent of suburban teachers have hometowns in urban regions. ${ }^{3}$ Although distance may play a role in these results, it is also the case that apart from distance, the culture of schools or communities may play some role in the segmentation of teacher labor markets.

Urban districts typically are net importers of teachers from the suburbs. In Buffalo, New York City, Rochester and Syracuse, the ratio of those with suburban hometowns who take jobs in the city relative to those with urban hometowns who take jobs in the suburbs ranges from 2.6 (Buffalo) to about 7.5 (New York City). Thirty percent of the teachers taking their first job in New York City public schools had hometowns in the New York City suburbs. The need for urban schools to import teachers, in combination with preferences to be close to home or in areas with characteristics similar to home increases the difficulty of recruitment for urban districts.

Much has been made of the difficulty of recruiting math, science and special education teachers. As a result, one might imagine that the effect of distance and the pull of home may differ by field of specialization, as recruitment efforts would be more intense in difficult-to-staff subjects. Table 6 gives the distance from hometown and college to first job, by area of primary teaching responsibility. There is little evidence that labor market geography for difficult-to-staff teaching specialties differs from that for other teaching areas.

These descriptive analyses suggest that individuals typically take jobs very close to their hometowns, and to a lesser extent, close to the college or university from which they obtained

\footnotetext{
3 Again, these patterns are supported when location of most recent college is substituted for hometown location. Eighty-four percent of individuals who obtained their most recent degree in New York City first taught there.
} 
their most recent degree prior to their first job. The analyses also suggest that the urbanicity of the schools may play some role apart from distance. To gain a better perspective on the role that these and other factors might play in the identification of relevant labor markets for prospective teachers we model these decisions in a multivariate framework.

A model of teacher job search. Ultimately, the specific schools where individuals first teach reflect a two-sided match between employers and employees and as a result, the preferences of both the teachers and the administrators who hire them. We have addressed this two-sided matching process in a related paper by simultaneously estimating the preferences of both sides of the market (Boyd, Lankford, Loeb, and Wyckoff, 2003), The intent of this paper is different. We examine teachers' first-job preferences across geographic regions. The assumption that, while teachers may not be able to choose the specific school they teach in, they are able to choose the region, allows us to limit the problem to an unconstrained choice model for teachers. We estimate the region in which a teacher selects his/her first job as a function of teacher characteristics and characteristics of the region, including distance from hometown and college.

In our analysis, teachers choose the location of their first job from one of 17 different regions of New York State described above. Because there are numerous opportunities for prospective teachers to find jobs within each region, it is reasonable to assume that teachers can unilaterally choose to focus job search within one of these regions. Table 7 summarizes the hiring of teachers in school districts and schools for each of the 17 regions during the 2000-01 school year. Most of the urban areas contain only one school district, but each of these districts typically has many schools hiring numerous first-year teachers in any given year. Regional averages indicate that there were more than 1000 novice teachers hired in more than 240 different schools in 2000-01. The region with the smallest number hired more than 50 teachers in 20 different schools. Thus there are numerous opportunities for entering teachers within each region. As shown in Table 8, the number of districts and schools hiring and the number of positions filled have remained fairly stable across the years in our analysis. As is the case nationally, hiring increased in more recent years.

We assume that teacher $m$ maximizes utility, $U_{m j}$, by selecting a region $j$ in which to begin teaching. This region is one of $J$ mutually exclusive regions in which he/she could teach. Region $j$ is chosen so long as $U_{m j}>U_{m k}$ for all $k \neq j$. In our empirical model, we specify $U_{m j}$ as a 
function of distance from the region to the teacher's hometown, distance from the region to the college where the most recent degree was earned, individual attributes of the teacher, regional attributes, and a random error term. Employing a standard random utility model, we assume that the error term is Gumbel-distributed implying a multinomial logit specification. The probability that a teacher chooses to locate in region $j$ is:

$$
\operatorname{Prob}(J=j)=\frac{e^{\beta_{j}^{\prime} x_{i}}}{1+\sum_{k=1}^{17} e^{\beta_{k}^{\prime} x_{i}}} .
$$

Where the $x_{\mathrm{i}}$ are defined as:

Distance from home to each region in a cubic functional form Home distance interacted with:

Female: equals 1 if the individual is female, 0 otherwise

SAT: individuals combined math and verbal SAT scores

Urban: equals 1 if region is urban, 0 otherwise

Rural: equals 1 if the region is rural, 0 otherwise

Region is home: equals 1 if the region is the home region; 0 otherwise

Region is home interacted with urban and rural

Region and home same type: equals 1 if region and home are of same urbanicity

Region and home same type interacted with urban and rural:

Region is other portion of home metro: equals 1 if region is other portion of home MSA, 0 otherwise

Distance from college to each region in a cubic functional form

Distance from college interacted with female and rural

Graduated from college in region: equals 1 if individual received most recent higher education degree from an institution in the region, 0 otherwise

Since choices among regions are relative to each other, variables that do not interact with regional attributes are irrelevant to the choice. We allow teachers' evaluations of the importance of distance to vary by individual attributes. For example, higher ability teachers may value distance from hometown differently than do lower ability teachers.

We estimate the model with observations for 33,474 first-time teachers who took jobs in New York State public schools from 1998-99 to 2001-02. Parameter estimates and odds ratios for the estimated model are shown in Table $9 .{ }^{4}$ Distance from hometown is both statistically and

\footnotetext{
${ }^{4}$ To examine the sensitivity of the analysis to the definition of region, we also run the multinomial logit estimates for 10 regions where each of the seven MSAs was defined as a single region (collapsing the urban and suburban portions of each). We do this out of concern that teachers in urban schools, for example, could not find any jobs in the corresponding suburban area. The results of this analysis, reported on Appendix Table B-3, are substantially the same as those for the 17 regions, as reported below. None of the major conclusions of the paper are altered.
} 
quantitatively important to teachers' location decisions. As shown in Figure 1, an individual is twice as likely to teach in a region that is within five miles of his or her hometown as one 20 miles away and about four times as likely to teach in a region within five miles of his or her hometown as one 40 miles away. A beginning teacher is more than three times as likely to teach in a region 25 miles from her hometown as one 80 miles away. Teachers place a premium on searching for jobs close to their hometowns, other things equal including distance from college.

First-year teachers also have strong preferences to locate in regions similar to that of their hometowns, other things (including distance) equal. For example, a new teacher whose hometown is in an urban area is three times as likely to locate in that urban area, as he/she is to locate in the suburban portion of the same metropolitan area (Table 10). However, again holding distance constant, a teacher is just as likely to locate in his or her home region, as he/she is to locate in the urban portion of another metropolitan area. Suburban teachers express a stronger preference for their home region. Controlling for distance, a teacher with a suburban hometown is 4.5 times as likely to locate there as in the urban portion of the same metropolitan area and three times as likely to locate in that suburban region as a suburban region in a different metropolitan area. Thus, a prospective teacher who grew up in a particular suburban area is much more likely to take a job in that suburban region, relative to urban and rural areas. Among suburban regions, they show strong preference for their hometown region relative to the suburban region of another metropolitan areas (Figure 2 and Table 10). Prospective teachers whose hometown is in a rural region prefer to locate in other rural regions relative to urban or suburban locations, although this preference is not as strong as those with urban or suburban hometowns. The strong preferences of teachers for locating in the region of their hometown, or to a lesser extent, a region of similar urbanicity may reflect a variety of social and cultural factors, but these preferences have important implications for the recruitment of teachers to urban, low-performing schools.

Both distance and hometown region have powerful effects on individuals' employment location decisions but what is the relative importance of these factors? In terms of the tradeoffs implied by the parameter estimates, an individual whose hometown was in a suburban region

In order to test whether missing data is likely to bias our estimates, we run models that omit the variables related to hometown for the sample of observations with hometown information and for the sample for which hometown was missing. See Appendix Table B-4. The results across these two samples are substantially the same and none of the major conclusions presented are altered. 
would be indifferent between locating in another suburban region that is 5 miles away and the hometown region if that region were 31 miles away. In other words, the value of working in their hometown region, relative to another suburban region, is worth traveling 26 miles further. When comparing the hometown region and a region of a different type, the individual would be indifferent if the hometown region were 37 miles further away. Finally, an individual would be willing to travel 5 miles further to work in another suburban region rather than a different type of region. Recall that reasonably small differences in distance can lead to relatively large changes in the odds ratio of locating in a particular place, e.g. an increase of 15 miles can lead to a doubling of the odds ratio. This implies that the effects of hometown region are substantial relative to distance, but that the effect of locating in a region of a similar type is much more modest.

The importance of distance to an individual varies only slightly by the individual's own attributes. For example, an individual with a total SAT score of 1000 is three times as likely to locate in a region 5 miles from her hometown as one 31 miles from her hometown, other things equal (Figure 3, base case). An otherwise identical individual with a 1200 SAT score would have the same odds ratio for a region 35 miles away. Thus more qualified teachers are willing to expand their job search, but only slightly. The effects of gender and the region of your home, e.g., urban, are even smaller.

The model also suggests that holding distance to hometown constant, new teachers are sensitive to the distance from where they last obtained a college degree prior to starting their first job. New teachers are 36 percent more likely to locate in the region where they received their last degree relative to another region, other things equal (Figure 4). However, as shown in Table 11, proximity to hometown is substantially more influential than proximity to college location, except for individuals with urban hometowns. Female teachers who grew up in suburban regions but went to college in a different suburban location 20 miles away are more than 2.8 times as likely to teach in their hometown region as in the region where they attended college. Individuals with urban hometowns who attended colleges in urban regions are about as likely to teach in the region of their college as their hometown region. 


\section{Discussion and Conclusions}

In seeking their first teaching jobs, prospective teachers appear to search very close to their hometowns and in regions that are similar to those where they grew up. Location of college plays an independent, although less important role in teachers' employment location decisions. These conclusions are supported by descriptive statistics and our estimated behavioral model. Moreover, these results are robust to several alternative specifications.

The importance of distance in teachers' preferences particularly challenges urban districts, which are net importers of teachers. The number of teacher recruits whose hometown is in an urban area falls short of the number of positions being filled in urban districts, requiring that these districts attract teachers from other regions. ${ }^{5}$ Teacher candidates coming from suburban or rural hometowns strongly prefer to remain in those areas, rather than teach in the urban districts -- both because of the importance of distance and because teachers have preferences with respect to urbanicity. Thus urban districts must overcome these preferences in addition to addressing the considerations typically identified with recruiting teachers to difficultto-staff urban schools, such as salary, working conditions and the characteristics of the student population. In general, urban schools must have salaries, working conditions or student populations that are more attractive than those of the surrounding suburban districts to induce sufficiently qualified candidates whose hometowns are in suburban regions to take jobs further from home and in a different type of region. To the extent that they do not, teachers with suburban hometowns who take jobs in urban areas are likely to be less qualified than those who teach in the suburbs. Moreover, urban districts face a second disadvantage. If, historically, the graduates of urban high schools have not received adequate education, then the cities face a lessqualified pool of potential teachers even if they are not net importers. Preferences for proximity lead to the perpetuation of inequities in the qualifications of teachers. Inadequate education is a cycle that is difficult to break.

One strategy for attracting more qualified teachers from non-urban regions is to offer compensation for teaching in areas that are net importers of teachers. Boyd, Lankford, Loeb \& Wyckoff (2003) estimate these compensating differentials. A complementary strategy focuses on the recruitment of individuals living in the urban districts to teacher education programs and

\footnotetext{
${ }^{5}$ This is true for each of the major urban areas in New York (Buffalo, New York City, Rochester, Syracuse, and Yonkers).
} 
employment in urban schools - a "grow-your-own" strategy. Given the strong preferences for teaching close to home and that most students attend college close to home, an important part of the solution is likely to be partnerships between urban schools and higher-education institutions in close proximity to the district. This then places a premium on teacher preparation and recruitment in urban areas, where the graduates are most likely to become the teachers in difficult-to-staff urban schools. In addition to heightened recruitment efforts, increased compensation for urban teachers would increase the supply of urban residents to teaching.

The results have implications with respect to the geography of teacher labor markets more generally. The common practice of conceptualizing teacher labor markets as covering large regions, or the nation as a whole, can be quite misleading. Such a view leads to the conclusion that there is merely a mismatch in the geographical location of well-qualified teachers and the students who most need them. Our analysis implies that it may be more difficult than previously thought to create the incentives necessary to alleviate this mismatch. Rather, viewing teacher labor markets as geographically small focuses attention on the margins where incentives are most likely to be effective.

The small geographical scope of teacher labor markets also needs to be taken into account in empirical analyses. Proximity to home, home region and similarity to home region are important in teachers' employment preferences. Research examining compensating differentials that does not account for these job attributes will likely miss-estimate the compensation necessary to successfully recruit teachers. A substantial body of research estimates teachers' decisions to enter teaching, quit or transfer. Such research may also be misleading if it omits distance from the list of potential factors affecting teachers' choices.

Finally, many of the implications noted here may extend beyond public school teachers. Other street level professionals, especially those in the public sector, share attributes of public school teaching. Labor markets for these occupations are likely to be small, as well. As a result, recruiting more qualified public safety, health care, and social service workers may follow many of the policy recommendations noted above.

There is little research on the geography of labor markets. The research that has been done has tended to look within metropolitan areas, addressing questions of spatial mismatch and market segmentation. This paper takes a different approach, assessing employment location decisions across regions and using residential location in high school instead of current residence 
to define measures of distance. By doing this, we are able to limit our behavioral model to a one-sided choice and reduce the potential that home residence is endogenous to employment opportunities. The results show the importance of proximity for teachers and suggest the need to consider local supply when designing policies to affect the recruitment and retention of teachers. 
Figure 1: Likelihood of Locating in Two Non-Home Regions as a Function of Distance from Hometown to Employment Locations in Each Region

(Region 1 Relative to Region 2)

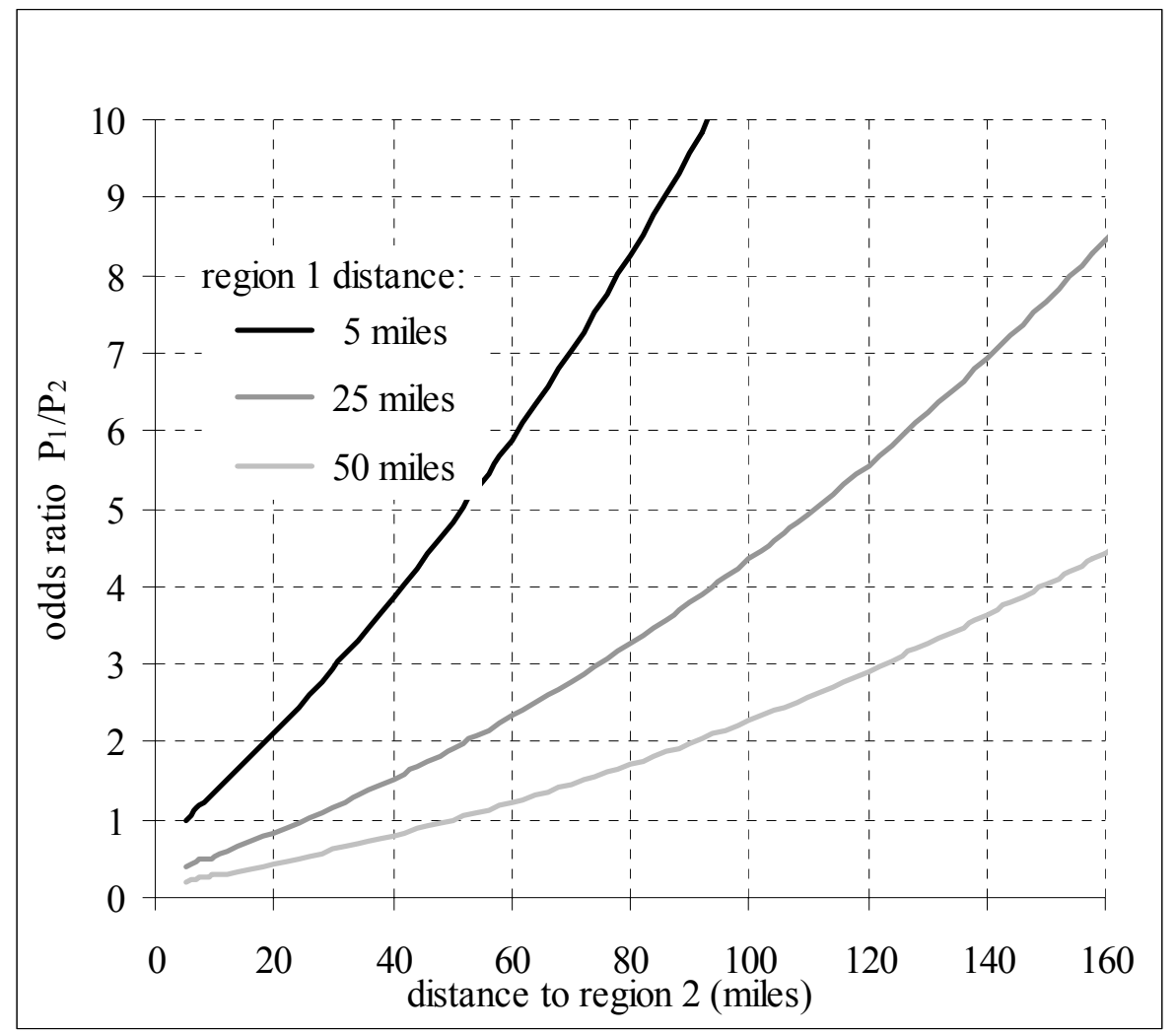


Figure 2: Likelihood of Locating in Two Regions as a Function of Similarity to Hometown and Distance (Region 1 Relative to Region 2 for Individual whose Hometown is a suburban region)

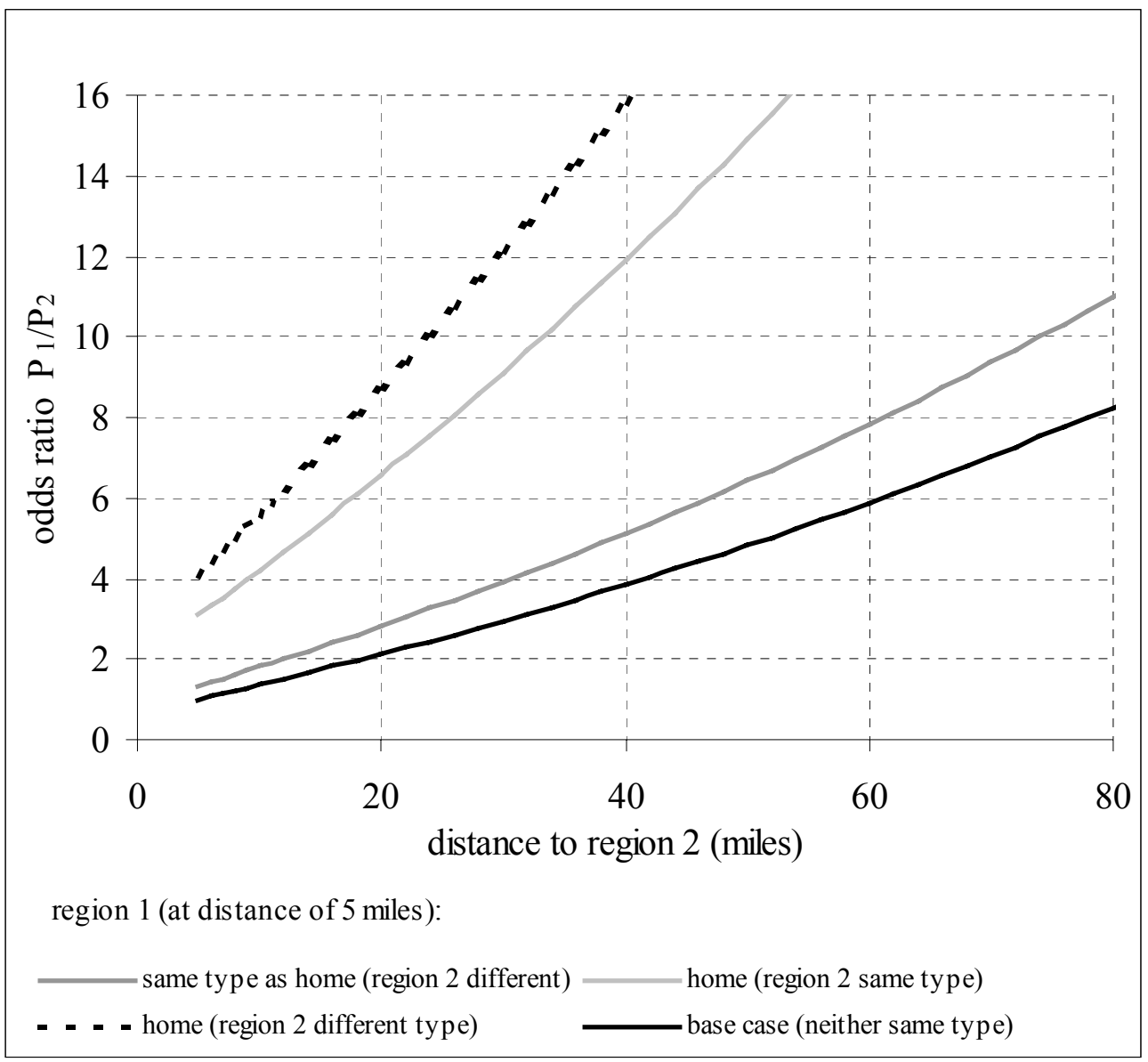


Figure 3: Likelihood of Locating in Two Regions with Alternative Distance from Hometown and Varying Teacher Attributes (Region 1 Relative to Region 2, Region 1 Distance Equals 5 Miles)

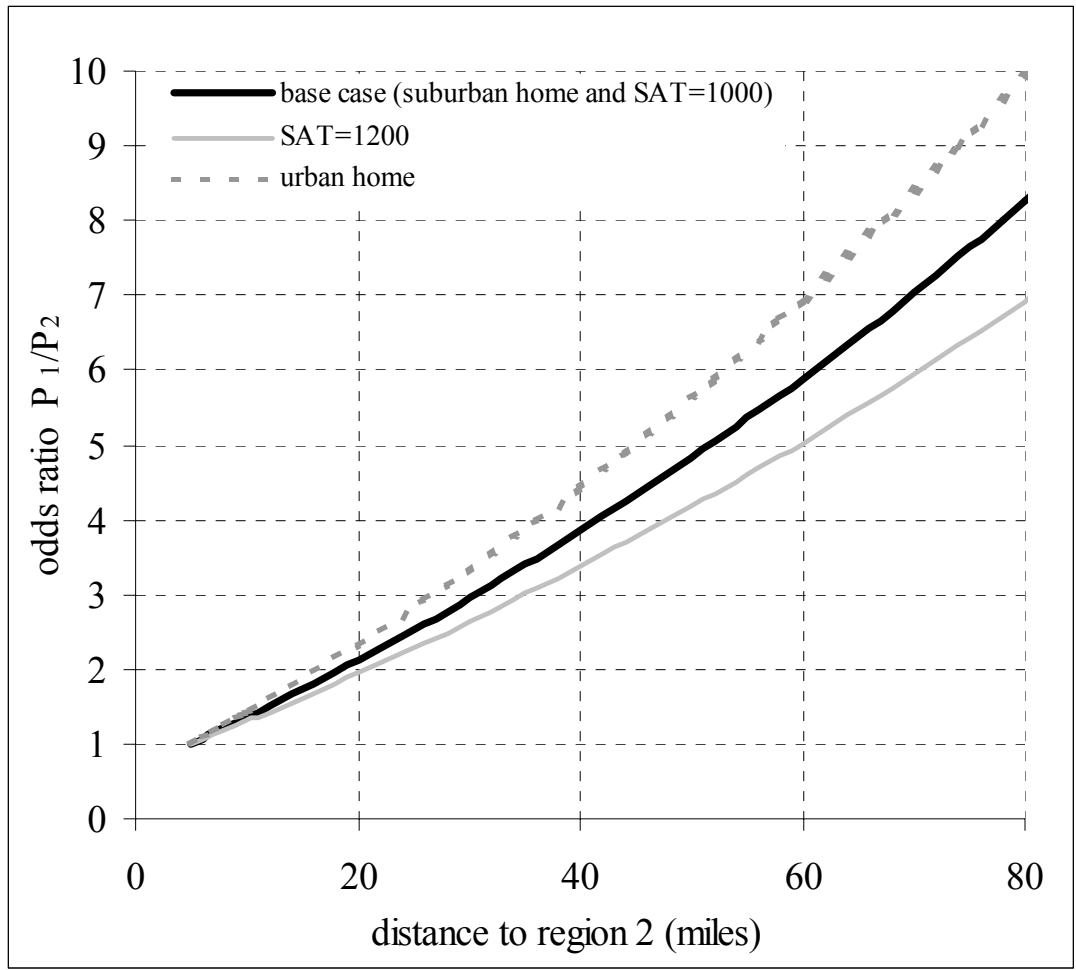

Figure 4: Likelihood of Locating in Two Regions for Alternative Location of Colleges and Distance to Region (Region 1 Relative to Region 2, Region 1 Distance Equals 5 Miles)

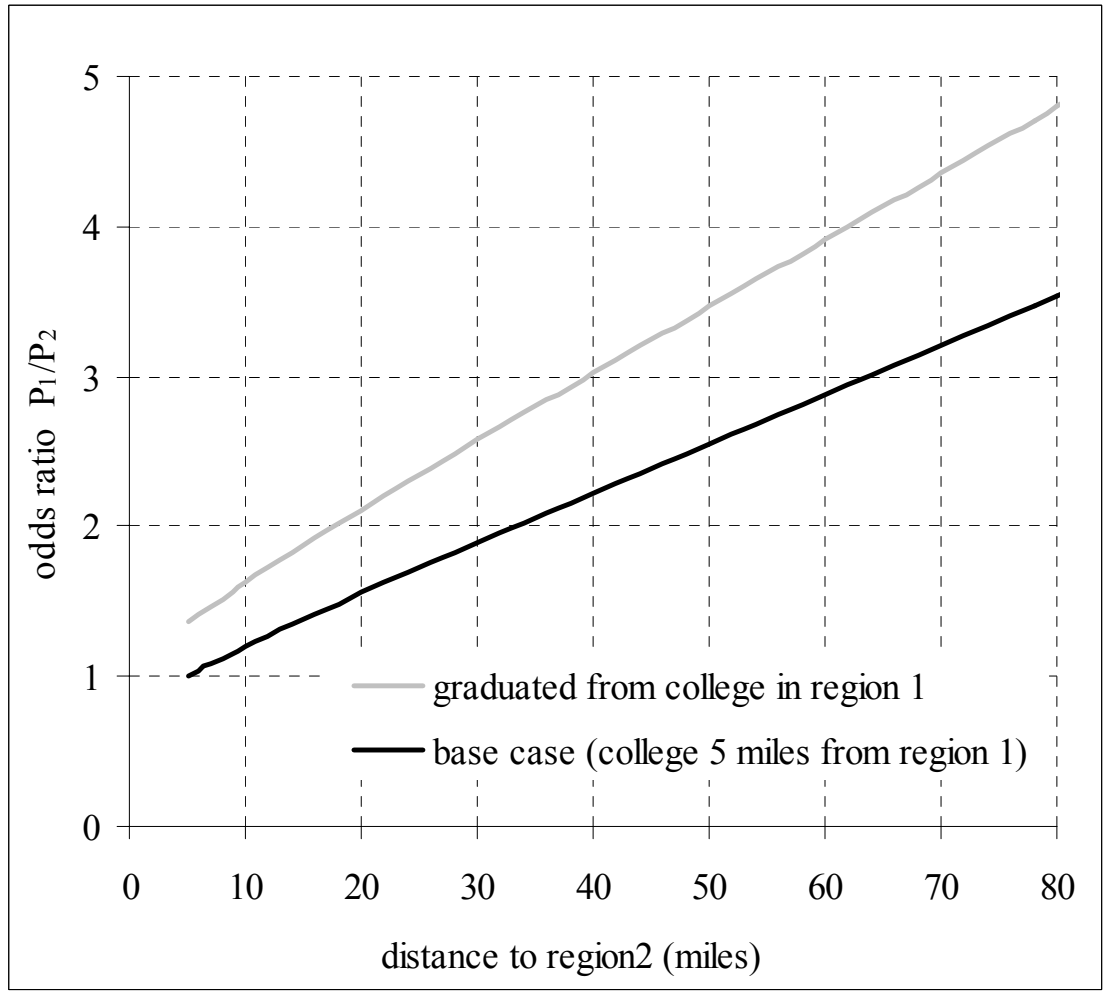




\section{Table 1: Average School Attributes of Teachers by Student Test Score-4 ${ }^{\text {th }}$ Grade ELA Level 1, 2000}

\begin{tabular}{|c|c|c|c|c|}
\hline \multirow[t]{2}{*}{ Teacher Quality Attributes } & \multicolumn{4}{|c|}{ Percent of Students in Level 1 4th Grade ELA } \\
\hline & 0 & $0 \%$ to $<5 \%$ & $5 \%$ to $<20 \%$ & $>20 \%$ \\
\hline Overall Teacher Quality Factor & $0.98^{* *}$ & $0.86^{* *}$ & $-0.30^{* *}$ & -2.82 \\
\hline$\%$ with No Teaching Experience & $0.06^{* *}$ & $0.07^{* *}$ & $0.09^{* *}$ & 0.14 \\
\hline$\%$ Not Certified in any Assignment & $0.03^{* *}$ & $0.04^{* *}$ & $0.09^{* *}$ & 0.22 \\
\hline \% Fail NTE Gen. Know. or NYS Lib. Arts Exam & $0.09^{* *}$ & $0.10^{* *}$ & $0.19^{* *}$ & 0.35 \\
\hline$\%$ BA from Most Competitive College & $0.11^{* *}$ & $0.11^{* *}$ & 0.09 & 0.08 \\
\hline$\%$ BA from Least Competitive College & $0.10^{* *}$ & $0.11^{* *}$ & $0.16^{* *}$ & 0.26 \\
\hline
\end{tabular}

Statistical significance refers to differences between other student performance levels and the $>20 \%$ level for each of the mean teacher attributes: $\sim p<.01 ;{ }^{*} p<.05 ;{ }^{* *} p<.01$.

Table 2: Distance From Home to First Job by MSA, 1999-2002

Distance from Home to First Job

\begin{tabular}{lcccc} 
Region of First Job & $\begin{array}{c}\text { 0 to } \mathbf{1 5} \\
\text { miles }\end{array}$ & $\begin{array}{c}\mathbf{1 5} \text { to } \mathbf{4 0} \\
\text { miles }\end{array}$ & $\mathbf{4 0}$ to $\mathbf{1 0 0}$ miles & $\begin{array}{c}\mathbf{1 0 0} \text { or more } \\
\text { miles }\end{array}$ \\
\hline Buffalo City & & & & \\
Buffalo suburbs & 76.0 & 10.3 & 3.7 & 9.9 \\
New York City & 71.0 & 18.3 & 4.3 & 6.3 \\
New York City Suburbs & 63.4 & 26.9 & 6.6 & 3.1 \\
Rochester City & 71.0 & 22.7 & 3.6 & 2.8 \\
Rochester Suburbs & 54.2 & 11.4 & 18.7 & 15.8 \\
Syracuse City & 44.8 & 25.9 & 18.2 & 11.2 \\
Syracuse Suburbs & 77.7 & 5.6 & 6.1 & 10.6 \\
Other & 51.5 & 24.6 & 11.9 & 12.0 \\
All & 48.2 & 24.0 & 14.3 & 13.5 \\
& 60.8 & 23.9 & 8.6 & 6.7
\end{tabular}


Table 3: Distance from Home to Most Recent College, and Home to First Job, 1997-2002

\begin{tabular}{|c|c|c|c|c|c|c|}
\hline \multirow{2}{*}{$\begin{array}{l}\text { Distance from } \\
\text { Home to Job }\end{array}$} & & \multicolumn{5}{|c|}{ Distance from Home to College } \\
\hline & & $\begin{array}{l}0 \text { to } 15 \\
\text { miles }\end{array}$ & $\begin{array}{c}15 \text { to } 40 \\
\text { miles }\end{array}$ & $\begin{array}{l}40 \text { to } 100 \\
\text { miles }\end{array}$ & $\begin{array}{c}100 \text { or more } \\
\text { miles }\end{array}$ & All \\
\hline \multirow[t]{2}{*}{0 to 15 miles } & $\%$ Col Total & 75.6 & 55.2 & 49.4 & 48.0 & 61.0 \\
\hline & \% Row Total & 51.0 & 17.8 & 12.3 & 18.8 & 100.0 \\
\hline \multirow[t]{2}{*}{15 to 40 miles } & $\%$ Col Total & 20.1 & 34.2 & 20.8 & 24.0 & 23.9 \\
\hline & \% Row Total & 34.7 & 28.1 & 13.2 & 24.0 & 100.0 \\
\hline \multirow[t]{2}{*}{40 to 100 miles } & $\%$ Col Total & 2.8 & 8.1 & 23.7 & 8.9 & 8.5 \\
\hline & $\%$ Row Total & 13.8 & 18.8 & 42.3 & 25.1 & 100.0 \\
\hline \multirow[t]{2}{*}{100 or more miles } & $\%$ Col Total & 1.4 & 2.5 & 6.2 & 19.1 & 6.6 \\
\hline & $\%$ Row Total & 8.9 & 7.6 & 14.2 & 69.4 & 100.0 \\
\hline \multirow[t]{2}{*}{ All } & PctN & 41.2 & 19.7 & 15.2 & 23.9 & 100.0 \\
\hline & $\mathbf{N}$ & 15,891 & 7,598 & 5,861 & 9,238 & 38,588 \\
\hline
\end{tabular}


Table 4: Region of Home by Region of First Job, 1999-2002

Region of Job

\begin{tabular}{|c|c|c|c|c|c|c|c|c|c|c|c|}
\hline & & $\begin{array}{l}\text { New York } \\
\text { City }\end{array}$ & $\begin{array}{l}\text { New York } \\
\text { City } \\
\text { Suburbs }\end{array}$ & $\begin{array}{c}\text { Buffalo } \\
\text { City }\end{array}$ & $\begin{array}{l}\text { Buffalo } \\
\text { suburbs }\end{array}$ & $\begin{array}{l}\text { Rochester } \\
\text { City }\end{array}$ & $\begin{array}{l}\text { Rochester } \\
\text { Suburbs }\end{array}$ & $\begin{array}{c}\text { Syracuse } \\
\text { City }\end{array}$ & $\begin{array}{l}\text { Syracuse } \\
\text { Suburbs }\end{array}$ & Other & All \\
\hline \multicolumn{12}{|l|}{$\begin{array}{l}\text { Region of High } \\
\text { School }\end{array}$} \\
\hline \multirow[t]{2}{*}{ New York City } & \% Row Total & 91.8 & 6.1 & 0.1 & 0.1 & 0.2 & 0.1 & 0.1 & 0.1 & 1.4 & 100.0 \\
\hline & $\begin{array}{l}\text { \%Col Total } \\
\% \text { Row Total }\end{array}$ & 65.4 & 6.3 & 1.9 & 0.5 & 2.4 & 0.3 & 3.3 & 0.4 & 1.5 & 24.1 \\
\hline \multirow{2}{*}{$\begin{array}{l}\text { New York City } \\
\text { Suburbs }\end{array}$} & & 31.0 & 63.3 & 0.1 & 0.2 & 0.2 & 0.6 & 0.1 & 0.3 & 4.2 & 100.0 \\
\hline & \%Col Total & 30.1 & 88.9 & 1.5 & 1.3 & 3.6 & 2.7 & 3.3 & 3.0 & 6.1 & 32.9 \\
\hline \multirow[t]{2}{*}{ Buffalo City } & \% Row Total & 5.9 & 0.5 & 45.4 & 33.9 & 2.6 & 3.8 & 0.2 & 0.9 & 6.8 & 100.0 \\
\hline & \%Col Total & 0.2 & 0.0 & 28.3 & 6.8 & 1.3 & 0.6 & 0.3 & 0.3 & 0.3 & 1.0 \\
\hline \multirow[t]{2}{*}{ Buffalo suburbs } & $\%$ Row Total & 1.2 & 1.1 & 13.4 & 59.2 & 1.8 & 10.6 & 0.1 & 0.7 & 11.9 & 100.0 \\
\hline & \%Col Total & 0.2 & 0.3 & 55.9 & 79.6 & 6.2 & 10.9 & 1.2 & 1.5 & 3.6 & 7.0 \\
\hline \multirow[t]{2}{*}{ Rochester City } & $\%$ Row Total & 4.7 & 0.5 & 0.5 & 0.5 & 54.9 & 30.6 & 0.0 & 2.1 & 6.2 & 100.0 \\
\hline & \%Col Total & 0.1 & 0.0 & 0.1 & 0.0 & 12.6 & 2.1 & 0.0 & 0.3 & 0.1 & 0.5 \\
\hline \multirow[t]{2}{*}{ Rochester Suburbs } & $\%$ Row Total & 1.9 & 1.4 & 0.8 & 2.6 & 16.8 & 64.1 & 0.2 & 1.8 & 10.4 & 100.0 \\
\hline & \%Col Total & 0.4 & 0.4 & 2.9 & 3.3 & 52.7 & 61.3 & 1.2 & 3.5 & 2.9 & 6.5 \\
\hline \multirow[t]{2}{*}{ Syracuse City } & $\%$ Row Total & 9.7 & 1.8 & 0.6 & 1.2 & 1.8 & 3.0 & 46.7 & 24.8 & 10.3 & 100.0 \\
\hline & \%Col Total & 0.1 & 0.0 & 0.1 & 0.1 & 0.4 & 0.2 & 23.2 & 3.0 & 0.2 & 0.4 \\
\hline \multirow[t]{2}{*}{ Syracuse Suburbs } & \% Row Total & 2.3 & 1.8 & 0.9 & 0.9 & 2.5 & 8.9 & 11.0 & 51.6 & 20.1 & 100.0 \\
\hline & \%Col Total & 0.3 & 0.3 & 2.2 & 0.8 & 5.1 & 5.6 & 57.5 & 65.9 & 3.7 & 4.3 \\
\hline \multirow[t]{2}{*}{ Other } & $\%$ Row Total & 4.8 & 3.7 & 0.5 & 1.7 & 1.4 & 4.7 & 0.3 & 3.1 & 79.8 & 100.0 \\
\hline & \%Col Total & 3.3 & 3.7 & 6.9 & 7.6 & 15.7 & 16.2 & 9.9 & 22.1 & 81.6 & 23.4 \\
\hline \multirow[t]{2}{*}{ All } & PctN & 33.9 & 23.4 & 1.7 & 5.2 & 2.1 & 6.7 & 0.8 & 3.3 & 22.9 & 100.0 \\
\hline & $\mathbf{N}$ & 13826 & 9564 & 681 & 2113 & 839 & 2752 & 332 & 1359 & 9359 & 40825 \\
\hline
\end{tabular}


Table 5: Urbanicity of Home by Urbanicity of first Job, 1999-2002

\begin{tabular}{llcccc} 
& & \multicolumn{3}{c}{ Region of First Job } & \\
\cline { 3 - 4 } Region of Home & Urban & Suburban & Rural & All \\
\hline \multirow{3}{*}{ Urban } & & & & \\
& \% Row Total & 87.8 & 10.4 & 1.8 & 100.0 \\
Suburban & \%Col Total & 59.9 & 6.4 & 2.9 & 27.1 \\
\multirow{3}{*}{ Rural } & \% Row Total & 25.7 & 66.9 & 7.4 & 100.0 \\
& \%Col Total & 36.1 & 85.7 & 24.6 & 55.8 \\
& \% Row Total & 9.2 & 20.0 & 70.9 & 100.0 \\
& \%Col Total & 4.0 & 7.9 & 72.4 & 17.1 \\
& PctN & 39.7 & 43.6 & 16.7 & 100.0 \\
& N & 16290 & 17871 & 6872 & 41033
\end{tabular}

Table 6: Distance From Home to First Job by Teaching Assignment, 1999-2002

\begin{tabular}{lcccc} 
& \multicolumn{4}{c}{ Distance From Home to First Job } \\
\cline { 2 - 5 } Teaching Assignment & $\begin{array}{c}\text { 0 to } \mathbf{1 5} \\
\text { miles }\end{array}$ & $\begin{array}{c}\mathbf{1 5} \text { to } \mathbf{4 0} \\
\text { miles }\end{array}$ & $\begin{array}{c}\mathbf{4 0} \text { to } \mathbf{1 0 0} \\
\text { miles }\end{array}$ & $\begin{array}{c}\mathbf{1 0 0} \text { or more } \\
\text { miles }\end{array}$ \\
\cline { 1 - 4 } Elementary & & & & \\
Humanities & 64.7 & 22.8 & 7.4 & 5.1 \\
Math & 57.0 & 25.1 & 9.8 & 8.1 \\
Science & 60.8 & 23.9 & 8.6 & 6.8 \\
Fine art & 55.6 & 25.6 & 9.8 & 9.0 \\
Other Ed & 57.1 & 22.9 & 9.5 & 10.5 \\
Occupational Ed & 57.5 & 24.1 & 9.7 & 8.7 \\
Special Ed & 57.4 & 24.8 & 9.1 & 8.7 \\
ESL & 59.1 & 24.8 & 9.3 & 6.8 \\
All & 62.8 & 23.7 & 6.8 & 6.8 \\
& 60.8 & 23.9 & 8.6 & 6.7
\end{tabular}


Table 7: Number of Units Hiring and Number of New Hires by MSA, 2001

\begin{tabular}{llll} 
& \multicolumn{2}{c}{ Units with Hires } & Number \\
Region & Districts & Schools & of Hires
\end{tabular}

\begin{tabular}{lccc} 
Alb/Sch/Troy City & 3 & 38 & 140 \\
Alb/Sch/Troy suburbs & 51 & 178 & 573 \\
Buffalo City & 1 & 70 & 295 \\
Buffalo suburbs & 40 & 208 & 773 \\
New York City & 1 & 1140 & 7517 \\
New York City Suburbs & 189 & 1019 & 3892 \\
Rochester City & 1 & 58 & 425 \\
Rochester Suburbs & 63 & 249 & 1054 \\
Syracuse City & 1 & 34 & 137 \\
Syracuse Suburbs & 46 & 176 & 522 \\
Utica/Rome City & 2 & 20 & 55 \\
Utica/Rome suburbs & 24 & 66 & 159 \\
Midhudson & 90 & 313 & 1073 \\
Southern Tier & 115 & 362 & 1266 \\
N.Country & 91 & 213 & 639 \\
\hline All & 718 & 4144 & 18520
\end{tabular}

Table 8: Total Number of Units Hiring and Number of New Hires by Year

\begin{tabular}{lccc} 
& \multicolumn{2}{c}{ Units with Hires } & Number \\
& Districts & Schools & of Hires \\
\hline $\mathbf{1 9 9 9}$ & 707 & 3925 & 16080 \\
$\mathbf{2 0 0 0}$ & 711 & 4040 & 16965 \\
$\mathbf{2 0 0 1}$ & 718 & 4144 & 18520 \\
$\mathbf{2 0 0 2}$ & 713 & 4036 & 18148 \\
\hline Average & 708 & 3915 & 15960
\end{tabular}


Table 9: Estimated Multinomial Logit Model of Employment Location Choice

\begin{tabular}{|c|c|c|c|}
\hline Variables & Coefficient & Odds ratio & Z statistics \\
\hline \multicolumn{4}{|l|}{ Distance from home } \\
\hline In(distance) & -0.361 & .697 & -7.19 \\
\hline $\ln (\text { distance })^{2}$ & -0.077 & .926 & -30.57 \\
\hline In(distance)3 & -0.009 & .991 & -15.78 \\
\hline In(distance) * female & -0.019 & .981 & -1.36 \\
\hline * SAT & 0.0003 & 1.000 & 7.80 \\
\hline * urban & -0.067 & .935 & -2.39 \\
\hline${ }^{*}$ rural & 0.049 & 1.050 & 1.42 \\
\hline Region is home & 1.128 & 3.090 & 21.43 \\
\hline Region is home * urban & -1.117 & .327 & -7.90 \\
\hline Region is home * rural & -0.306 & .736 & -3.00 \\
\hline Region and home same type & 0.286 & 1.331 & 2.80 \\
\hline Region and home same type * urban & 0.710 & 2.035 & 5.97 \\
\hline Region and home same type * rural & 0.058 & 1.059 & 0.43 \\
\hline Region is other portion of home metro & -0.096 & .908 & -1.94 \\
\hline \multicolumn{4}{|l|}{ Distance from college } \\
\hline In(distance) & 0.027 & 1.027 & 1.38 \\
\hline $\ln (\text { distance })^{2}$ & -0.050 & 0.951 & -19.01 \\
\hline $\ln (\text { distance })^{3}$ & -0.007 & 0.993 & -13.74 \\
\hline In(distance) ${ }^{*}$ female & -0.047 & 0.954 & -3.16 \\
\hline * rural & 0.194 & 1.214 & 9.09 \\
\hline Graduated from college in region & 0.388 & 1.475 & 10.17 \\
\hline $\begin{array}{l}\text { Log Likelihood } \\
\text { Sample size }\end{array}$ & & $\begin{array}{r}-31,384 \\
33,474\end{array}$ & \\
\hline
\end{tabular}


Table 10: Effects of Location Similarity New of Distance Effects 1999-2002, Odds Ratio of First Job Being in Home Region v. Various Alternatives

\begin{tabular}{|c|c|c|c|c|}
\hline \multirow{3}{*}{ Individual having } & \multicolumn{4}{|c|}{ Alternative Region } \\
\hline & \multirow{2}{*}{$\begin{array}{l}\text { Other part of same } \\
\text { metropolitan area }\end{array}$} & \multicolumn{2}{|c|}{ Another metropolitan area } & Another \\
\hline & & Urban portion & Suburban portion & Rural area \\
\hline
\end{tabular}

$\begin{array}{lcccc}\text { Urban home } & 3.01 & 1.01 & 2.74 & 2.74 \\ \text { Suburban home } & 4.52 & 4.11 & 3.09 & 4.11 \\ \text { Rural home } & \mathrm{n} / \mathrm{a} & 3.21 & 3.21 & 2.28\end{array}$

Table 11: Relative Importance of Proximity to Home and Proximity to College as Determinants of First Employment Location (Odds Ratio of home region v. college location for females)

\begin{tabular}{cccc}
$\begin{array}{c}\text { Distance between } \\
\text { Regions }\end{array}$ & $\begin{array}{c}\text { Suburban home } \\
\text { \& alternatives }\end{array}$ & $\begin{array}{c}\text { Urban home } \\
\text { \& alternatives }\end{array}$ & $\begin{array}{c}\text { Urban home } \\
\text { \& alternatives }\end{array}$ \\
\hline 20 miles & 2.76 & 0.99 & 2.49 \\
40 miles & 3.37 & 1.27 & 3.36
\end{tabular}




\section{References}

Ballou, D. and M. Podgursky, (1997) Teacher Pay and Teacher Quality, Kalamazoo MI: W.E. Upjohn Institute for Employment Research.

Boyd, D., H. Lankford, S. Loeb, J. Wyckoff (2002), Initial Matches, Transfers, and Quits: The Role of Teachers' Career Decisions in the Disparities in Average Teacher Qualifications Across Schools, working paper.

Boyd, D., H. Lankford, S. Loeb, J. Wyckoff (2003) Analyzing the Determinants of the Matching of Public School Teachers to Jobs, working paper.

Gregory, R. and J. Borland, (1999), "Recent Developments in Public Sector Labor Markets," in O. Ashenfelter and D. Card eds., Handbook of Labor Economics, Volume 3C, Elsevier: Amsterdam, chapter 53.

Hanson, S. and G. Pratt (1992), "Dynamic Dependencies: A Geographic Investigation of Local Labor Markets, Economic Geography, 68(4), p. 373-405.

Lankford, H., S. Loeb, J. Wyckoff (2002), "Teacher Sorting and the Plight of Urban Schools: A Descriptive Analysis" Educational Evaluation and Policy Analysis, Spring, p.

Martin, R. (2000) “Local Labor Markets: Their Nature, Performance, and Regulation," in G. Clark, M. Feldman, and M. Gerthler, eds., The Oxford Handbook of Economic Geography, Oxford University Press, chapter 23.

Murnane, R., J. Singer, J. Willett, J. Kemple, and R. Olsen (1991) Who Will Teach? Policies that Matter, Cambridge MA: Harvard University Press.

Scott, A., (1992) "The Spatial Organization of a Local Labor Market: Employment and Residential Patterns in a Cohort of Engineering and Scientific Workers," Growth and Change, Winter, p. 94-115.

Strauss, R. (1999) "Who Gets Hired to Teach? The Case of Pennsylvania," in M. Kanstroom and C. Finn, Better Teachers, Better Schools, Fordham Foundation. 
Appendix A: Workforce Database

\begin{tabular}{|c|c|c|c|c|c|}
\hline & Personnel data & $\begin{array}{c}\text { Certification and } \\
\text { exam data }\end{array}$ & SUNY student data & $\begin{array}{c}\text { School and district } \\
\text { data }\end{array}$ & College Board data \\
\hline UNIVERSE: & $\begin{array}{l}\text { All public school } \\
\text { teachers, } \\
\text { superintendents, } \\
\text { principals, and other } \\
\text { staff }\end{array}$ & $\begin{array}{l}\text { All individuals taking } \\
\text { certification exams }\end{array}$ & $\begin{array}{l}\text { All SUNY applicants } \\
\text { (including non- } \\
\text { teachers) }\end{array}$ & $\begin{array}{l}\text { All public schools and } \\
\text { districts }\end{array}$ & $\begin{array}{l}\text { All students taking the } \\
\text { SAT in New York } \\
\text { schools }\end{array}$ \\
\hline ELEMENTS: & $\begin{array}{l}\text { - salary } \\
\text { - course subject and } \\
\quad \text { grade } \\
\text { - class size } \\
\text { - experience (district } \\
\quad \text { and other) } \\
\text { - years of education and } \\
\quad \text { degree attainment } \\
\text { - age } \\
\text { - gender }\end{array}$ & $\begin{array}{l}\text { - scores on NTE and } \\
\text { NYSTCE (general } \\
\text { knowledge, } \\
\text { pedagogy, and } \\
\text { content specialty) } \\
\text { exams } \\
\text { - college of } \\
\text { undergraduate } \\
\text { and } \\
\text { graduate degrees } \\
\text { - degrees earned } \\
\text { - zipcode of } \\
\text { residence } \\
\text { when certified } \\
\text { - race }\end{array}$ & $\begin{array}{l}\text { - high school attended } \\
\text { - high school courses } \\
\text { - high school GPA } \\
\text { - SAT exam scores } \\
\text { - college attended and } \\
\text { dates } \\
\text { - intended college } \\
\quad \text { major } \\
\text { - actual college major } \\
\text { - college GPA } \\
\text { - degrees earned }\end{array}$ & $\begin{array}{l}\text { - enrollment } \\
\text { - student poverty (free } \\
\quad \text { and reduced lunch } \\
\text { counts) } \\
\text { - enrollment by race } \\
\text { - limited English } \\
\quad \text { proficiency } \\
\text { - student test results } \\
\text { - dropout rates } \\
\text { - district wealth } \\
\text { - district salary } \\
\text { schedule } \\
\text { - support staff and } \\
\text { aides }\end{array}$ & $\begin{array}{l}\text {-SAT scores } \\
\text {-zip code of address }\end{array}$ \\
\hline TIME PERIOD: & $1969-70$ to $2001-02$ & $1984-85$ to $2001-02$ & $1989-90$ to $1999-00$ & $1969-70$ to $2001-02$ & 1980 to 2001 \\
\hline SOURCE: & $\begin{array}{l}\text { New York State } \\
\text { Education Department }\end{array}$ & $\begin{array}{l}\text { New York State } \\
\text { Education } \\
\text { Department }\end{array}$ & $\begin{array}{l}\text { The State University of } \\
\text { New York }\end{array}$ & $\begin{array}{l}\text { New York State } \\
\text { Education Department }\end{array}$ & College Board \\
\hline
\end{tabular}




\section{Appendix B}

Table B-1: Distance from High School to Job by Distance

From Most Recent College to First job 1999-2002

\begin{tabular}{|c|c|c|c|c|c|c|c|}
\hline \multirow{2}{*}{$\begin{array}{c}\text { Distance College } \\
\text { Job }\end{array}$} & & \multicolumn{6}{|c|}{ Distance High School to Job } \\
\hline & & $\begin{array}{l}0 \text { to } 15 \\
\text { miles }\end{array}$ & $\begin{array}{l}15 \text { to } 40 \\
\text { miles }\end{array}$ & $\begin{array}{l}40 \text { to } 100 \\
\text { miles }\end{array}$ & $\begin{array}{l}100 \text { or more } \\
\text { miles }\end{array}$ & Missing & All \\
\hline \multirow[t]{3}{*}{0 to 15 miles } & \% Row Total & 44.8 & 8.3 & 2.8 & 2.5 & 41.6 & 100 \\
\hline & $\%$ Col Total & 46.2 & 21.8 & 20.3 & 22.9 & 37.2 & 36.8 \\
\hline & $\mathbf{N}$ & 11517 & 2130 & 713 & 631 & 10696 & 25687 \\
\hline \multirow[t]{3}{*}{15 to 40 miles } & \% Row Total & 33.9 & 25.1 & 5.1 & 3.6 & 32.4 & 100 \\
\hline & $\%$ Col Total & 18.7 & 35.2 & 19.9 & 17.8 & 15.4 & 19.7 \\
\hline & $\mathbf{N}$ & 4659 & 3446 & 697 & 489 & 4443 & 13734 \\
\hline \multirow[t]{3}{*}{40 to 100 miles } & \% Row Total & 38.6 & 19 & 13.8 & 4.6 & 24 & 100 \\
\hline & $\%$ Col Total & 11.8 & 14.7 & 29.8 & 12.7 & 6.3 & 10.9 \\
\hline & $\mathbf{N}$ & 2937 & 1444 & 1046 & 349 & 1823 & 7599 \\
\hline \multirow[t]{3}{*}{100 or more miles } & \% Row Total & 34.8 & 17.4 & 6.5 & 8.4 & 32.8 & 100 \\
\hline & $\%$ Col Total & 17.8 & 22.6 & 23.5 & 39 & 14.5 & 18.2 \\
\hline & $\mathbf{N}$ & 4423 & 2211 & 823 & 1073 & 4170 & 12700 \\
\hline \multirow[t]{3}{*}{ Missing } & \% Row Total & 13.7 & 5.6 & 2.3 & 2.1 & 76.3 & 100 \\
\hline & $\%$ Col Total & 5.5 & 5.7 & 6.5 & 7.6 & 26.5 & 14.3 \\
\hline & $\mathbf{N}$ & 1371 & 559 & 227 & 210 & 7626 & 9993 \\
\hline \multirow[t]{4}{*}{ All } & \% Row Total & 35.7 & 14 & 5 & 3.9 & 41.3 & 100 \\
\hline & $\%$ Col Total & 100 & 100 & 100 & 100 & 100 & 100 \\
\hline & PctN & 35.7 & 14 & 5 & 3.9 & 41.3 & 100 \\
\hline & $\mathbf{N}$ & 24907 & 9790 & 3506 & 2752 & 28758 & 69713 \\
\hline
\end{tabular}


Table B-2: Distance from Place of Most Recent Degree to First Job, by MSA, 2000

\begin{tabular}{lccccc}
\multicolumn{1}{c}{ Region } & $\begin{array}{c}\mathbf{0} \text { to } \mathbf{1 5} \\
\text { miles }\end{array}$ & $\begin{array}{c}\mathbf{1 5} \text { to } \mathbf{4 0} \\
\text { miles }\end{array}$ & $\begin{array}{c}\mathbf{4 0} \text { to } \mathbf{1 0 0} \\
\text { miles }\end{array}$ & $\begin{array}{c}\mathbf{1 0 0} \text { or } \\
\text { more } \\
\text { miles }\end{array}$ & Total \\
\hline $\begin{array}{l}\text { Buffalo City } \\
\text { Buffalo suburbs }\end{array}$ & 79.8 & 7.6 & 7.0 & 5.6 & 100.0 \\
New York City & 51.5 & 25.9 & 15.3 & 7.3 & 100.0 \\
New York City Suburbs & 64.9 & 9.6 & 5.8 & 19.7 & 100.0 \\
Rochester City & 36.3 & 29.2 & 9.2 & 25.3 & 100.0 \\
Rochester Suburbs & 42.8 & 30.1 & 15.6 & 11.6 & 100.0 \\
Syracuse City & 24.7 & 34.8 & 23.5 & 17.0 & 100.0 \\
Syracuse Suburbs & 28.6 & 29.3 & 12.0 & 30.1 & 100.0 \\
Other & 19.9 & 35.1 & 18.5 & 26.6 & 100.0 \\
All & 21.7 & 24.7 & 26.4 & 27.1 & 100.0 \\
& 45.4 & 20.1 & 12.8 & 21.6 & 100.0
\end{tabular}


Table B-3: Examination of Estimation Robustness: Employing Metropolitan-wide Alternatives

\begin{tabular}{|c|c|c|c|c|c|c|}
\hline & \multicolumn{3}{|c|}{$\begin{array}{l}\text { (1) } \\
\text { Primary Model (Urban and } \\
\text { Suburban Alternatives) }\end{array}$} & \multicolumn{3}{|c|}{$\begin{array}{c}(2) \\
\text { Primary Model with Metro- } \\
\text { wide Alternatives }\end{array}$} \\
\hline & Coefficient & $\begin{array}{l}\text { Odds } \\
\text { ratio }\end{array}$ & $\begin{array}{c}\mathrm{Z} \\
\text { statistics }\end{array}$ & Coefficient & $\begin{array}{l}\text { Odds } \\
\text { ratio }\end{array}$ & $\begin{array}{c}\mathrm{Z} \\
\text { statistics }\end{array}$ \\
\hline \multicolumn{7}{|l|}{ Distance from home } \\
\hline $\ln ($ distance) & -0.361 & .697 & -7.19 & 0.2888 & 1.33 & 2.69 \\
\hline $\ln (\text { distance })^{2}$ & -0.077 & .926 & -30.57 & -0.3547 & 0.70 & -9.74 \\
\hline In(distance)3 & -0.009 & .991 & -15.78 & 0.0264 & 1.03 & 6.40 \\
\hline In(distance) * female & -0.019 & .981 & -1.36 & -0.0194 & 0.98 & -1.17 \\
\hline${ }^{*}$ SAT & 0.0003 & 1.000 & 7.80 & 0.0004 & 1.00 & 7.59 \\
\hline * urban & -0.067 & .935 & -2.39 & -0.0733 & 0.93 & -3.36 \\
\hline${ }^{*}$ rural & 0.049 & 1.050 & 1.42 & 0.0292 & 1.03 & 1.22 \\
\hline Region is home & 1.128 & 3.090 & 21.43 & 1.0357 & 2.82 & 19.31 \\
\hline Region is home * urban & -1.117 & .327 & -7.90 & & & \\
\hline Region is home * rural & -0.306 & .736 & -3.00 & & & \\
\hline Region and home same type & 0.286 & 1.331 & 2.80 & 0.0886 & 1.09 & 2.52 \\
\hline Region and home same type * urban & 0.710 & 2.035 & 5.97 & & & \\
\hline Region and home same type * rural & 0.058 & 1.059 & 0.43 & & & \\
\hline Region other portion of home metro & -0.096 & .908 & -1.94 & & & \\
\hline \multicolumn{7}{|l|}{ Distance from college } \\
\hline In(distance) & 0.027 & 1.027 & 1.38 & -0.2332 & 0.79 & -2.12 \\
\hline $\ln (\text { distance })^{2}$ & -0.050 & 0.951 & -19.01 & 0.0883 & 1.09 & 2.02 \\
\hline $\ln (\text { distance })^{3}$ & -0.007 & 0.993 & -13.74 & -0.0221 & 0.98 & -4.59 \\
\hline In(distance) * female & -0.047 & 0.954 & -3.16 & -0.0700 & 0.93 & -3.79 \\
\hline${ }^{*}$ rural & 0.194 & 1.214 & 9.09 & 0.1928 & 1.21 & 8.79 \\
\hline Graduated from college in region & 0.388 & 1.475 & 10.17 & 0.6206 & 1.86 & 9.51 \\
\hline $\begin{array}{l}\text { Log Likelihood } \\
\text { Sample size }\end{array}$ & \multicolumn{3}{|c|}{$-31,384$} & \multicolumn{3}{|c|}{$\begin{array}{r}-17,201 \\
33474\end{array}$} \\
\hline
\end{tabular}


Table B-4: Examination of Estimation Robustness: Estimation without Home Variables for Observations with and without Home Variables

\begin{tabular}{|c|c|c|c|c|c|c|}
\hline & \multicolumn{3}{|c|}{$\begin{array}{c}\text { (1) } \\
\text { Home Variables Not Missing }\end{array}$} & \multicolumn{3}{|c|}{$\begin{array}{c}(2) \\
\text { Home Variables Missing }\end{array}$} \\
\hline & Coefficient & $\begin{array}{l}\text { Odds } \\
\text { ratio }\end{array}$ & $\begin{array}{c}\mathrm{Z} \\
\text { statistics }\end{array}$ & Coefficient & $\begin{array}{l}\text { Odds } \\
\text { ratio }\end{array}$ & \begin{tabular}{|c}
$\mathrm{Z}$ \\
statistics
\end{tabular} \\
\hline \multicolumn{7}{|l|}{ Distance from college } \\
\hline $\ln$ (distance) & -0.0415 & 0.96 & -2.82 & -0.0899 & 0.91 & -4.59 \\
\hline $\ln (\text { distance })^{2}$ & -0.0875 & 0.92 & -36.19 & -0.1006 & 0.90 & -34.76 \\
\hline $\ln (\text { distance })^{3}$ & -0.0095 & 0.99 & -23.43 & -0.0079 & 0.99 & -15.03 \\
\hline $\ln ($ distance $){ }^{*}$ female & -0.0826 & 0.92 & -8.09 & -0.1248 & 0.88 & -8.48 \\
\hline${ }^{*}$ rural & 0.1548 & 1.17 & 10.87 & 0.2168 & 1.24 & 9.99 \\
\hline Graduated from college in region & 0.1297 & 1.14 & 4.42 & 0.5042 & 1.66 & 11.82 \\
\hline $\begin{array}{l}\text { Log Likelihood } \\
\text { Sample size }\end{array}$ & \multicolumn{3}{|c|}{$-50,132$} & \multicolumn{3}{|c|}{$-28,034$} \\
\hline
\end{tabular}

